\title{
POU-domain transcription factors: pou-er-ful developmental regulators
}

\author{
Michael G. Rosenfeld \\ Howard Hughes Medical Institute, Eukaryotic Regulatory Biology Program, University of California, San Diego, School of \\ Medicine, La Jolla, California 92093-0648 USA
}

Genetic analyses have suggested that complex networks of interacting developmental regulators expressed in overlapping temporal and spatial patterns ultimately lead to activation of regulatory genes that specify organ development and cell phenotypes (for review, see Nüsslein-Volhard and Wieschaus 1980; Sternberg and Horvitz 1984; Akam 1987; Gehring 1987; Ingham 1988; Scott et al. 1989; Olson 1990). Many of these developmental loci encode sequence-specific DNA-binding proteins, presumably transcription factors, that share specific DNA-binding motifs conserved throughout evolution. This paper reviews the characterization of a gene family that contains a novel DNA-binding motif-the POU domain-which appears to exert critical developmental actions, providing insights into the mechanisms by which distinct cellular phenotypes emerge during organogenesis. This review will also summarize the known POU-domain factors, the unique features of their interactions with cognate DNA-binding sites, and the recent evidence of their specific developmental and transcriptional functions.

The highly conserved POU domain was initially recognized after the simultaneous cloning of three mammalian transcription factors and a Caenorhabditis elegans developmental regulator. Many additional POU-domain proteins have been identified subsequently and they are expressed in distinct temporal and spatial patterns during development. Developmental mutants resulting from disruption of two POU-domain genes have provided direct evidence that POU-domain transcription factors exert critical functions in the proliferation of specific cell types, as well as in the activation of specific programs of gene expression that define specific cell phenotypes within an organ. Several POU-domain regulators appear in early embryogenesis, a time at which no homeo domain proteins have yet been identified, which implies roles for them in the early developmental regulation of gene transcription. A striking feature of the, where no POU-domain gene family is that most of these genes are expressed in the mammalian forebrain, where no classic homeo domain proteins have yet been identified. These findings are consistent with functions for POU-domain proteins in the development of this evolutionarily recent brain structure.

What, then, are likely to be the roles of the POU do- main that may confer specific advantages in regulating organogenesis? Analysis of several POU-domain-specific proteins has defined roles for the POU domain in highaffinity, site-specific DNA sequence recognition and in protein-protein interactions. POU-domain proteins interact with cognate DNA recognition elements in a fundamentally different fashion from the classic homeo domain proteins, in that both portions of the bipartite POU domain apparently contact DNA, thereby constituting a functionally distinct class of regulatory proteins. POUdomain proteins exert either positive or negative transcriptional effects by binding to recognition elements as monomers or as homodimers formed as a consequence of DNA-dependent cooperative interactions. The POU domain may expand the potential diversity of transcriptional effects, because specific members of the POU-domain gene family can form heterodimeric complexes; one consequence of this is actually to prevent DNA binding and transcriptional activation of specific target genes. Finally, the POU domain may exert unique functions with regard to stimulation of DNA replication.

\section{Identification of a large family of POU-domain transcription factors}

The constantly expanding family of POU-domain genes was initially identified through analyses of cell-specific and general transcription factors. Analysis of an anterior pituitary-specific transcription factor that bound to related cis-active motifs in the rat prolactin (Prl) and growth hormone $(\mathrm{GH})$ genes and the B-cell-specific and ubiquitous octamer-binding proteins permitted the identification and cloning of cDNAs that encode the transcription factors Pit-1 (GHF-1), Oct-2 (OTF-2), and the universal octamer-binding protein Oct-1 (OTF-1, NFIII) (Bodner et al. 1988; Clerc et al. 1988; Finney et al. 1988; Ingraham et al. 1988; Ko et al. 1988; Müller et al. 1988; Scheidereit et al. 1988; Sturm et al. 1988). Pit-1 and Oct2 serve as transcription factors, activating expression of appropriate fusion genes in heterologous cell types (e.g., Ingraham et al. 1988, 1990; Müller et al. 1988; Gerster et al. 1990; Müller-Immerglück et al. 1990; Tanaka and Herr 1990). These three mammalian proteins and unc86, the gene encoding a regulator of cell fate in C. elegans (Chalfie et al. 1981), were found to share an extensively 


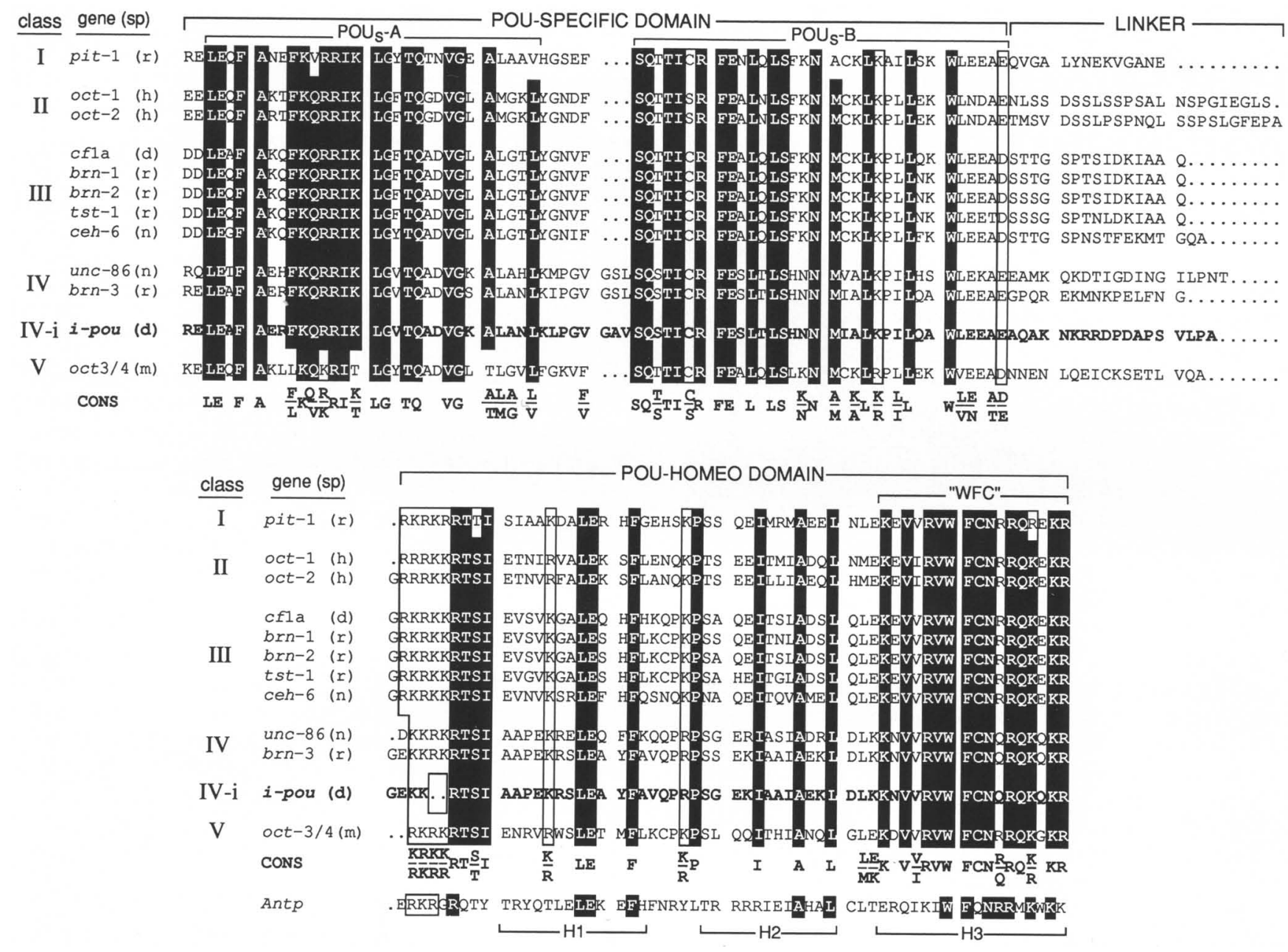

Figure 1. Comparison of the POU-domain sequence of a family of related POU-domain proteins. Homologies are indicated by black highlighting. The homeo domain of Antennapedia (Antp) is shown with positions of three helical domains, indicated as $\mathrm{H} 1, \mathrm{H} 2$, and H3. Species from which factors were cloned are rat $(\mathrm{r})$, C. elegans $(\mathrm{n})$, mouse $(\mathrm{m})$, and human $(\mathrm{h})$. The ${ }^{\mathrm{R}} / \mathrm{K}$ RI $\mathrm{K} / \mathrm{T}$ LG sequence in the pit-1 gene is the 3' terminus of an exon. The helical domains of the POU homeo domain and the basic residues at the amino terminus of this domain are encoded by separate exons. Alternative names for identified family members are Pit-1 (GHF-1); Oct-1 (OTF-1); Oct-2 (OTF-2; NFIII), cfla (D-POU-1); and Tst-1 (SCIP; Oct-6). (Cons) Consensus sequence.

conserved domain of $\sim 150$ amino acids called the POU domain (Herr et al. 1988). As summarized in Figure 1, numerous additional POU-domain genes in mammals, Drosophila, and C. elegans have been identified (Burglin et al. 1989; He et al. 1989; Johnson and Hirsh 1990; Monuki et al. 1990; Okamoto et al. 1990; Rosner et al. 1990; Schöler et al. 1990a; Suzuki et al. 1990). Post-transcriptional events generate further heterogeneity of POU-domain proteins, as exemplified in the case of alternative Oct-2 transcripts (e.g., Schreiber et al. 1988; Hatzopoulos et al. 1990).

\section{Structure of the POU domain}

The structural features of the POU domain will be reviewed because this region appears to confer several unique features. The POU domain varies from 147 to 156 amino acids in length and contains two major regions of very high homology-the POU-specific (POU $\left.{ }_{\mathrm{s}}\right)$ and POU-homeo domain $\left(\mathrm{POU}_{\mathrm{HD}}\right)$ (Fig. 1). The precise length of the $\mathrm{POU}_{\mathrm{S}}$ domain $(69-71$ or $76-78$ amino acids) depends on the arbitrary assignment of the amino-terminal boundary. The arbitrary assignment of the amino-terminal boundary of the $\mathrm{POU}_{\mathrm{S}}$ shown in Figure 1, which does not correspond to an intron-exon junction, includes all functionally critical information. Two distinct regions of particularly high homology, referred to as the $\mathrm{POU}_{\mathrm{s}}-\mathrm{A}$ region and the $\mathrm{POU}_{\mathrm{s}}-\mathrm{B}$ region, are noted (see Fig. 1). A poorly conserved spacer region, 14-25 amino acids long, separates the $\mathrm{POU}_{\mathrm{S}}$ domain from the 60-amino-acid $\mathrm{POU}_{\mathrm{HD}}$, highly conserved among POU-domain proteins and unambiguously related to the classic homeo domains found in Drosophila (Scott et al. 1989). The $\mathrm{POU}_{\mathrm{HD}}$ is predicted to contain three helices (Fig. 2), which correspond to those now established in the case of the classic homeo domain (Otting et al. 1988, 1990; Kiss- 


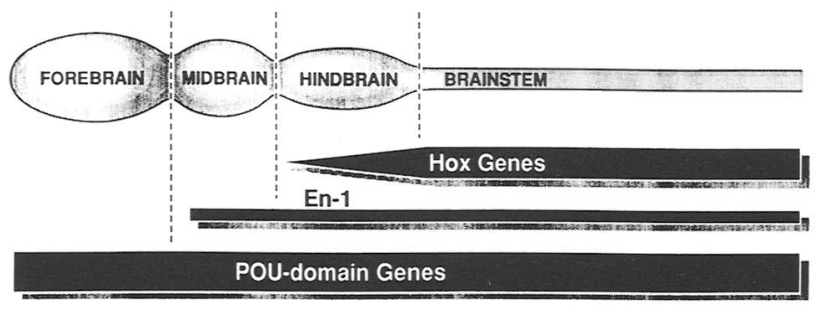

Figure 2. POU-domain proteins are expressed in the mammalian forebrain, in contrast to Hox genes, which are expressed in the hindbrain. Engrailed (en) homologs are detected in the midbrain.

inger et al. 1990), with the third "recognition" helix containing RVWFCN residues in all known members of the POU-domain gene family. On the basis of precedents in the homeo domain gene family, it is conceivable that the cysteine residue may not be invariant in the POU-domain gene family. Both amino- and carboxy-terminal boundaries of the $\mathrm{POU}_{\mathrm{HD}}$ and the amino terminus of the $\mathrm{POU}_{\mathrm{S}}$ domain contain clusters of basic amino acid residues, critical for their function as transcription factors (see below).

On the basis of the primary sequence throughout the POU domain, including the basic amino acid cluster at the amino terminus of the $\mathrm{POU}_{\mathrm{HD}}$ and patterns of highest conservation in the linker region separating the $\mathrm{POU}_{\mathrm{S}}$ and $\mathrm{POU}_{\mathrm{HD}}$ domains, the POU-domain proteins may be classified into five groups (POU-I to POU-V) (Fig. 1). Although the spacer region of Oct-1 has been shown to be functionally capable of accommodating additional residues for in vitro binding (Sturm and Herr 1988), the conservation of the spacer in different classes of POUdomain proteins suggests a functional role. Outside the POU domain, there is enormous divergence between all known family members. However, in concert with many other families of transcription factors, many members of the POU-domain gene family contain regions rich in specific amino acids, including serine/threonine-rich (Pit-1, Oct-1, and Oct-2), glutamine-rich (Brn-2, Oct-1, Oct-2), and glycine/alanine-rich (Tst-1/SCIP(suppressed cAMPinduciblePOU|/Oct-6) domains.

\section{POU-domain protein trans-activation regions}

POU-domain proteins appear to function as positive or negative transcriptions factors with the major transcriptional activating domain $(\mathrm{s})$ of known members of this family located outside of the POU domain (Theill et al. 1989; Ingraham et al. 1990; Müller-Immerglück et al. 1990; Tanaka and Herr 1990). The serine/threonine-rich regions of Oct-1 (OTF-1) and Oct-2 (OTF-2) transfer transcriptional function (Tanaka and Herr 1990), and a comparable serine/threonine-rich region serves as the major activation domain of the Pit-1 (GHF-1) protein (Theill et al. 1989; Ingraham et al. 1990). The alternative transactivation domains for Oct-2 may depend on the response element tested (Müller-Immerglück et al. 1990). While Pit-1, Oct-2, and Brn-2 are positive transcriptional activators (Ingraham et al. 1988; Müller et al. 1988; He et al. 1989; Tanaka and Herr 1990), the widely expressed Oct-1 protein has been reported to activate transcription of only a distinct class of promoters (e.g., Tanaka et al. 1988 |, presumably dependent on the position and nature of the cis-active recognition elements. The Tst-1/SCIP/ Oct- 6 protein appears to have the capacity to regulate specific gene transcription both positively and negatively (He et al. 1991; Monuki et al. 1990; Suzuki et al. 1990), depending on the promoter analyzed (Po, a member of the immunoglobulin superfamily), or the octamer element, perhaps a sequence of the glycine/alanine-rich regions.

\section{POU-domain proteins are expressed in early embryogenesis and during forebrain development}

Analysis of the ontogeny of the POU-domain gene family has revealed that specific POU-domain proteins are expressed selectively throughout the course of mammalian development. The discovery that several POU-domain genes are expressed in germ-line cells and early embryogenesis suggests functions in early development. One POU-domain protein, referred to as Oct-3/4 /Okamoto et al. 1990; Rosner et al. 1990; Schöler et al. 1990), is expressed in the female germ line and embryonic ectoderm until gastrulation and is restricted to primordial germ cells by embryonic day 8.5 . The Tst-1/SCIP/Oct-6 gene product (He et al. 1989; Monuki et al. 1990; Suzuki et al. 1990) also appears early in development in the inner cell mass of mouse embryos, but subsequently is expressed in specific neurons and testes, and after birth in a temporally restricted fashion in myelinating glia (Schöler et al. 1989; Monuki et al. 1990; Suzuki et al. 1990; He et al. 1991). Oct-3/4 and Tst-1/SCIP/Oct-6 are expressed in embryonic cell lines. Additional members of this family also appear to be expressed at these early times in development. Whereas a maternally derived classic homeo domain protein, bicoid, as well as dorsal, is crucial in Drosophila for establishing gradients that establish the developmental cascade of spatially specific transcription factor activation (Anderson 1987; Akam et al. 1987; Ingham et al. 1988), there are as yet no known mammalian maternally expressed homeo domain gene products.

From an apparently homogeneous population of neuroendothelial cells, brain development involves an intricate program of gene expression that leads to the establishment of a vast diversity of neuronal phenotypes and a precise, complex pattern of connections between them. The evidence that novel POU-domain proteins are expressed with distinct spatial and temporal patterns during establishment of the nervous system has raised the intriguing possibility that these proteins exert specific roles in specifying neuronal phenotypes. Hybridization histochemistry has revealed that all known POUdomain transcripts, except Oct-3/4, are expressed in all levels of the neural tube during at least some period of development. All transcripts are expressed in the ventricular (proliferative) zone of the neuroepithelium, 
which gives rise to the central nervous system (He et al. 1989), with subsequent restriction to specific neurons. For example, the $B r n-3$ gene transcript exhibits a highly restricted pattern that includes sensory ganglion cells, which are derived from the neural crest (He et al. 1989). In contrast, Brn-1 and Brn-2 transcripts (see Fig. 1) are expressed in almost all regions of the cerebrum (layers II-V) and cerebellum (Purkinje cells), and their expression is correlated with all stages of establishment of cortical lamination. The Tst-1/SCIP/Oct-6 gene is expressed in the cerebral (layers V-VI) and cerebellar (granule cells) cortices and in many nuclei, but is also transiently expressed in myelinating glia (He et al. 1989; Monuki et al. 1990). The patterns of anatomical restriction in the developing nervous system tend to reflect the adult loci of expression, but the extent of restriction varies dramatically. Some transcripts, such as pit-1, are entirely restricted out of the central nervous system. Intriguingly, in contrast to classic homeo domain proteins, POU-domain proteins are widely expressed in the developing and mature forebrain and midbrain, suggesting that they may function in the development of neuronal phenotypes in this recently evolved brain region (see Fig. 2).

Neuronally expressed POU-domain gene products exert transcriptional effects in the central nervous system. Brn-2 expressed in the paraventricular nucleus of the hypothalamus, in cells expressing neuropeptides such as corticotropic releasing hormone (CRH), can bind to and activate the promoter of the CRH gene (X. He et al., unpubl.). Tst-1/SCIP/Oct-6, transiently expressed in glia in the proliferative phase preceding myelination, is potentially regulated by cAMP (Monuki et al. 1990). It is capable of binding to and negatively regulating a gene encoding a member of the immunoglobulin superfamily (Po), expressed in glia at this time (Monuki et al. 1990; He et al. 1991). In Drosophila, a POU-domain factor, highly homologous to the other mammalian members of the POU III class, cfla (Johnson and Hirsch 1989), is expressed in neuronal and epidermal tissues and can bind to and trans-activate a neuronal regulatory site within the dopa decarboxylase gene (Johnson and Hirsh 1990; Treacy et al. 19911.

\section{Developmental functions of POU-domain transcription factors}

The analysis of two genetic defects in POU-domain transcription units has provided direct evidence of the function of these proteins in activating the gene programs required for appearance and proliferation of specific cell phenotypes.

\section{C. elegans development}

Genetic analysis of C. elegans development revealed that a POU-domain gene, unc-86, is required for the commitments in several neuroblast lineages. Mutations in the unc-86 locus prevent mother cells from differen- tiating into daughter cells, with retention of maternal phenotype (Chalfie et al. 1981; Finney et al. 1988). Three affected lineages are shown in Figure 3A. In each case, the daughter cells continue to exhibit the phenotype of mother cells, and, therefore, specific types of neurons fail to appear. In the lineages shown, failure to express unc86 may lead either to inappropriate cell death or to appearance of neurons failing to serve specific functions. Recent analyses (Finney and Ruvkin 1990) have revealed expression of unc- 86 protein occurring several minutes after cell division in the nuclei of cells corresponding to those affected by the unc- 86 mutations, consistent with the proposed role of unc- 86 in modulating the pattern of gene expression that distinguishes daughter cells from mother cells. The molecular basis for asymmetric activation of unc-86 in only one of two daughter cells remains unknown, although it is apparently not dependent upon cell-cell interactions. Interestingly, the unc-86 protein is also expressed in a number of neuronal types, not linked by any known common marker, which do not disappear with genetic mutants of the unc-86 locus (Ruvkun and Finney 1991). It has been suggested that unc-86 directs the patterns of gene expression in these cells, modulating their mature phenotype.

The unc-86 mutant has also provided insight into combinatorial codes required to establish specific phenotypes. Thus, a homeo domain gene, mec-3, which is important in establishing specific neuronal phenotypes (Chalfie et al. 1989), depends on unc-86 function for its expression. However, the distribution of the encoded proteins within the nervous system indicates that expression of unc-86 is itself not sufficient to activate mec3.

\section{Mammalian development}

A mammalian mutant in the pit-1 locus provides insight into the molecular mechanisms that establish specific cell types within an organ. Expression of Pit-1 is normally confined to three cell types in the anterior pituitary gland, defined on the basis of the trophic factor elaborated. These are referred to as thyrotrophs (express thyroid-stimulating hormone- $\beta$ [TSH- $\beta$ )], lactotrophs (express Prl), and somatotrophs (express GH) (Simmons et al. 1990). Pit-1 transcripts and protein are initially expressed in the rat anterior pituitary gland on embryonic day 15 preceding the initial appearance of $\operatorname{Prl}$ and GH transcripts on embryonic days 16-17 (Dollé et al. 1990; Simmons et al. 1990). However, pit-1 gene expression is initially observed in thyrotrophs, considerably later than the initial appearance of TSH- $\beta$ gene expression (Simmons et al. 1990) (see Fig. 3B). Pit-1 has been independently demonstrated (e.g., Ingraham et al. 1988; Mangalam et al. 1989; Fox et al. 1990; Sharp and Cao $1990)$ to be capable of binding with high affinity and of trans-activating both the Prl and GH promoters, except for a report suggesting that Pit-1/GH-1 is capable only of selectively binding and activating the $\mathrm{GH}$ promoter (Castrillo et al. 1989).

One form of genetically transmitted dwarfism in mice, 

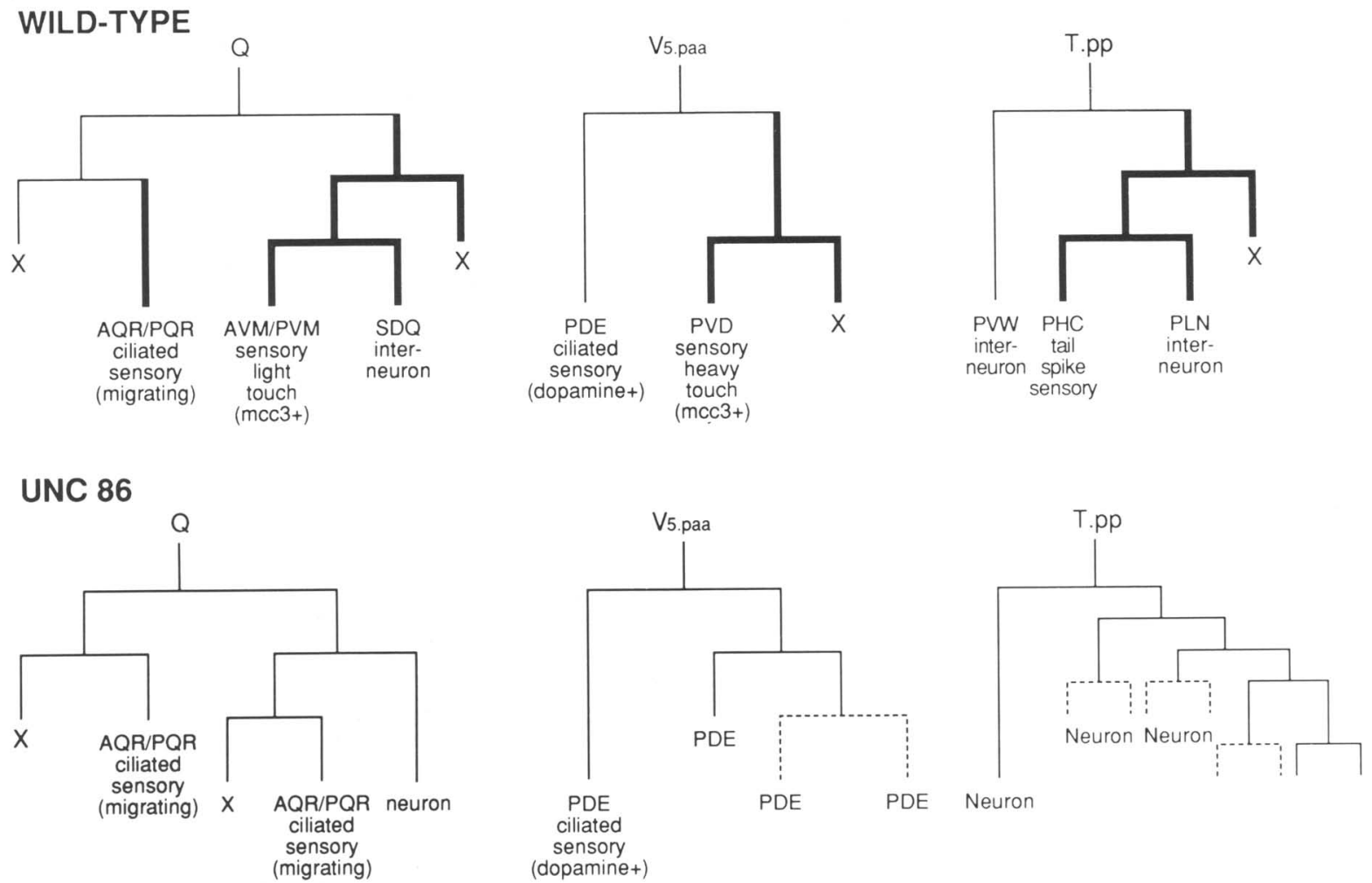

B

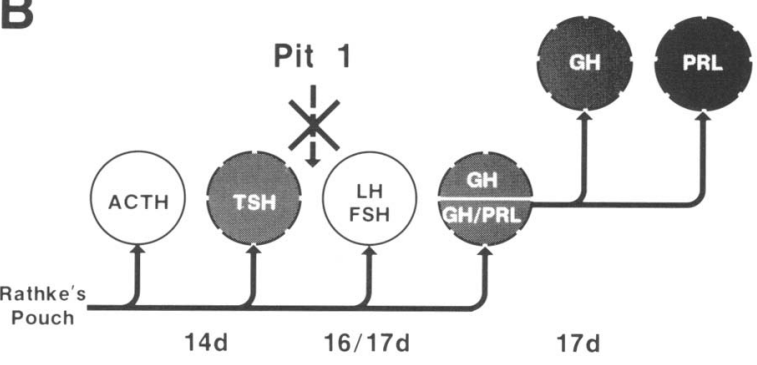

Figure 3. Developmental functions of unc-86 and pit-1. (A) Lineages of three neuronal cell lines. The heavy bar indicates expression of unc-86; expression occurs in cell types that are affected in the unc- 86 mutant. Note reiteration of maternal phenotypes in unc-86 mutants. (B) Effects of pit-1 on anterior pituitary development. pit-1 is normally expressed in thyrotrophs (TSH), somatotrophs (GH), and prolactin (PRL) cell types, which appear in the indicated stereospecific fashion. These cell types are depleted in genetic dwarfs harboring defects in the pit-1 gene (indicated by dashed lines), including thyrotrophs, which appear in normal mice before pit-1 gene expression is initially detected.

types (Lira et al. 1988; Crenshaw et al. 1989) probably requires additional activating and restrictive mechanisms.

The hypoplastic nature of the genetic dwarf pituitary provides direct evidence that cell proliferation and survival of specific cell types are important components of the program specified during normal development by Pit-1, reflecting either direct or indirect roles of Pit-1 in DNA replication. These data are consistent with the indication that Oct-1 and, potentially, other POU-domain proteins are strongly suggested to exert important functions in DNA replication. In available adenovirus in vitro replication assays, the POU domain of either Oct-1 (OTF-1, NFIII) or Oct-2 (OTF-2) was capable of enhancing in vitro DNA replication (Verrijzer et al. 1990a), while mutant proteins lacking the $\mathrm{POU}_{\mathrm{S}}$ domain were actually inhibitory in this replication assay.

These data indicate that combinatorial codes for both 
unc- 86 and Pit- 1 appear to be required for the quantitative and qualitative pattern of target gene expression. Thus, differential expression of the Pit-1-dependent Prl and $\mathrm{GH}$ target genes in distinct cell types, and unc-86dependent expression of mec-3 in specific neurons in $C$. elegans, must both reflect the actions of additional activating and restricting factors. In the thyrotroph cell type, which appears prior to detectable pit-1 gene expression, Pit-1 could potentially be required for survival or proliferation of this cell type and may exert functions comparable to those suggested for unc-86 in preventing programmed cell death. These data link POU-domain transcription factors to the proliferation of specific cell types, and progression and commitment events in organogenesis.

It is likely that other POU-domain proteins exert similar developmental functions. Because the octamer motif has been associated with lymphoid-specific immunoglobulin gene expression (Singh et al. 1986; Dreyfus et al. 1987; Wirth et al. 1987; Scheidereit et al. 1988), it is likely that Oct-2, in concert with other functions, also exerts determining functions in B-cell development and activation of immunoglobulin gene expression. Oct-3/4 maps to mouse chromosome 17 near or within the major histocompatibility complex (Schöler et al. 1990b), perhaps within loci that are associated with early embryonic lethal phenotypes.

\section{Functions of the POU domain}

The unique patterns of neuronal expression of the large family of POU-domain regulators make it particularly interesting to understand fully the functional properties conferred by the POU domain. Mutagenesis studies involving Pit-1 and Oct-1 suggest that both the POU $_{S}$ and $\mathrm{POU}_{\mathrm{HD}}$ are combinatorially required to permit high-affinity, site-specific binding. In the case of Pit-1, although the $\mathrm{POU}_{\mathrm{HD}}$ is sufficient for binding to a distinct set of A/T-rich DNA sequences with a relaxed specificity, the $\mathrm{POU}_{\mathrm{S}}$ domain is required for high-affinity, site-specific binding, increasing affinity up to 1000 -fold for physio-

POU-Domain:

Figure 4. Schematic representation of the POU domain, indicating predicted helical domains, and the most highly conserved sequences. The known functions of $\mathrm{POU}_{\mathrm{S}}$ and $\mathrm{POU}_{\mathrm{HD}}$ are listed above. These proteins bind to heterogeneous sites containing A/T-rich sequences; consensus sequences for Pit-1 and Oct-1 are shown below.

DNA Binding logic Pit-1 response elements (Ingraham et al. 1990). The $\mathrm{POU}_{\mathrm{S}}$ domain is similarly critical for high-affinity binding of Oct-1 to its recognition elements (Sturm and Herr 1988; Verrijzer et al. 1990b). Additionally, each of the three basic amino acid clusters at the amino terminus of the $\mathrm{POU}_{\mathrm{S}}$ domain and both amino and carboxyl termini of the $\mathrm{POU}_{\mathrm{HD}}$ serve critical functions in high-affinity DNA binding by POU-domain proteins, as mutations in any of these regions abolished high-affinity binding (Sturm and Herr 1988; Ingraham et al. 1990; Treacy et al. 1991). Creating POU-domain chimeras between Oct-1 and Pit-1 $\mathrm{POU}_{\mathrm{S}}$ and $\mathrm{POU}_{\mathrm{HD}}$ revealed that both domains exert critical functions in discriminating octamer- and Pit-1-binding sites (Ingraham et al. 1990). The invariant cysteine residue sequence in the $\mathrm{POU}_{\mathrm{HD}}$ "recognition helix" is apparently not absolutely required for high-affinity site-specific recognition, because mutation of this amino acid residue fails to affect Pit- 1 binding (Elsholtz et al. 1990; Ingraham et al. 1990). A comparable amino acid residue in classic homeo domain proteins has been suggested to dictate site-specific binding for several DNA sites (Hanes and Brent 1989; Treisman et al. 1989). Disruption of the predicted first helix (helix A; Fig. 4) in the $\mathrm{POU}_{\mathrm{S}}$ domain or helix 3 (WFC) in the $\mathrm{POU}_{\mathrm{HD}}$ abolishes DNA binding; however, disrupting the other putative helical structures in the $\mathrm{POU}_{\mathrm{S}}$ and $\mathrm{POU}_{\mathrm{HD}}$ does not affect binding (Fig. 4). This appears to be in contrast to the proposed hydrophobic helical interactions between helix 1 and helix 2 of the engrailed homeo domain protein that are required to present the minor groove contacts important for binding (Kissinger et al. 1990; Otting et al. 1990). This analysis of the $\alpha$-helical domains and conserved structures and the contacts of the POU domain on cognate sites suggests that POU-domain proteins interact with their DNA recognition sites differently from homeo domain proteins, with both the $\mathrm{POU}_{\mathrm{S}}$ and the $\mathrm{POU}_{\mathrm{HD}}$ contacting DNA. This formulation awaits high-resolution structural analysis.

Although the DNA-binding sites of classic homeo domain proteins generally are A/T-rich sequences, the best-described sites for POU-domain proteins for Oct-2, Oct -1 , and Pit-1 are variants of $(\mathrm{A} / \mathrm{T})_{4-5}$ TTTGCAT or

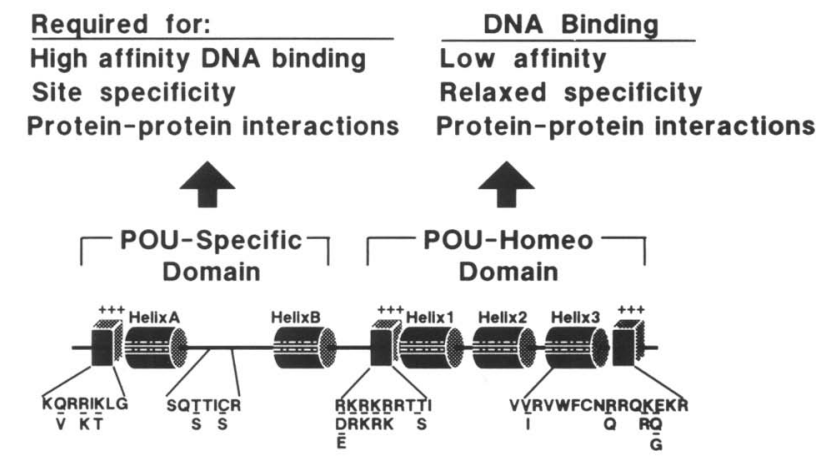
Consensus Sites: 
(A/T) ${ }_{45}$ TATNCAT, respectively (Wirth et al. 1987; Nelson et al. 1988; Elsholtz et al. 1990). Although additional data are clearly required, it has been suggested that $\mathrm{POU}_{\mathrm{S}}$ and $\mathrm{POU}_{\mathrm{HD}}$ interact with both the TATNCA and $\mathrm{A} / \mathrm{T}$-rich sequences in the binding site (Ingraham et al. 1990; Kristie et al. 1990; Verrijzer et al. 1990b). In this regard, it is interesting that the Pit-1 homeo domain can itself bind with relatively high affinity to certain recognition sites for the Drosophila homeo domain regulators (Ingraham et al. 1990), while the full POU domain fails to bind effectively to these sites. It is tempting to speculate that one advantage of this large, apparently asymmetric, recognition element is that post-translational regulation could impose differential binding, conformation, and functional effects on different subsets of cisactive elements, dependent upon sequences outside the canonical TATNCAT core-binding motif. For other sites, the $\mathrm{POU}_{\mathrm{s}}$ domain may not be critical for binding, as exemplified by Pit-1 binding on the engrailed site (Ingraham et al. 1990) and Oct-1 binding to the TAATGARAT sequence (Verrijzer et al. 1990b). These data together imply that the POU domain is functionally and structurally distinct from the homeo domain and that a subset of POU-domain-binding sites will be distinct from those containing the TATNCAT motif. For example, Tst-1 cis-active elements contain, instead, ATTA motifs (He et al. 1991). On the basis of all available data, it is suggested that the POU-domain-binding site is an asymmetric element spanning $12-15 \mathrm{bp}$, with the $\mathrm{POU}_{\mathrm{S}}$ domain contacting TATNCA sequences and the POU homeo domain also contacting, in variable conformations, A/T-rich sequences $5^{\prime}$ of the TATNCA core. Precise orientation of the $\mathrm{POU}_{\mathrm{S}}$ and $\mathrm{POU}_{\mathrm{HD}}$ on binding sites requires further experimentation.

\section{POU-domain protein-protein interactions}

The POU domain permits protein-protein interactions that may be critical for function. Pit-1, Oct-1, and Oct-2 have been described to behave as apparent monomers in solution (LeBowitz et al. 1989; Poellinger and Roeder 1989; Ingraham et al. 1990) and can bind as monomers to their cognate DNA recognition elements. Cooperative binding interactions are exhibited by Oct- 2 on an octamer element adjacent to a heptamer element on a natural binding site, and many of the Pit-1-binding sites in the rat Prl and GH promoters permit DNA-dependent Pit-1 dimer formation via cooperative binding interactions. (LeBowitz et al. 1989; Poellinger et al. 1989; Ingraham et al. 1990). Cooperative interactions between Oct2 proteins increase transcriptional activity (Poellinger et al. 1989). Many Pit-1-binding sites might be considered to contain direct repeats or palindromic arrangements of the TATNCA $(T)$ core motif, but it would appear that on certain sites Pit-1 binds preferentially and with high affinity as a monomer. On the basis of the precedents of Oct- 2 and Pit-1, it is suggested that specific cooperative binding may be a feature of many POU-domain proteins; however, these dimers apparently occur only on a subset of binding sites. Because the highly conserved RRIKLG sequence in the $\mathrm{POU}_{\mathrm{S}}-\mathrm{A}$ region represents the $3^{\prime}$ boundary of an exon in the pit-1 gene ( $\mathrm{Li}$ et al. 1990), it is tempting to speculate that the $\mathrm{POU}_{\mathrm{s}}-\mathrm{A}$ and $\mathrm{POU}_{\mathrm{s}}-\mathrm{B}$ regions may subserve differential functions with respect to protein-protein interactions and high-affinity, sequencespecific DNA binding. In addition to the ability to confer DNA-dependent protein-protein interactions, the POU domain may be important in formation of heterodimers on DNA and in solution between family members such as Oct-1 and Pit-1 that are often coexpressed in a single cell type (He et al. 1989; Voss et al. 1991), comparable to the functionally important heterodimers between members of other gene families (e.g., Rauscher et al. 1988; Glass et al. 1989; Murré et al. 1989a,b). Consistent with this possibility, DNA-independent interactions between specific POU-domain proteins have been observed in mammals and Drosophila (Treacy et al. 1991; Voss et al. 1991), alternatively promoting or inhibiting the binding of specific positive POU-domain regulators. I-POU (inhibitory-POU, see Fig. 1) specifically interacts with cfla, inhibiting its ability to bind and activate a specific neural promoter (Treacy et al. 1991). Because the relative levels of positive and inhibitory POU-domain proteins vary during development within specific neuronal and endocrine cell types, these types of protein-protein interactions may serve to impose sharp temporal and spatial boundaries, on the basis of stoichiometry of different POU-domain proteins.

Functional protein-protein interactions are also conferred by specific sequences in the $\mathrm{POU}_{\mathrm{HD}}$, established by the intriguing ability of Oct-1 to bind to the herpes virus $\alpha$ TIF/VP1 6 gene product, dependent on specific residues in helix 2 or the $\mathrm{POU}_{\mathrm{HD}}$ (McKnight et al. 1987; Gerster and Roeder 1988; O'Hare and Goding 1988; Stern et al. 1989|. $\alpha$ TIF/VP16 has been shown to interact with host Oct-1 protein in activation of viral early genes (O'Hare and Goding 1988; Preston et al. 1988). This apparently involves the formation of a complex with a third protein (Kristie et al. 1989; Gerster et al. 1990). The mutation of the three critical residues in the $P U_{H D}$ helix 2 to those present in Oct- 2 significantly decreases the $\alpha$ TIF/VP16 binding (Stern et al. 1989). Mammalian homologs of $\alpha$ TIF/VP16 have yet to be established. In the context of specific promoters, perhaps due to actions of additional factors, the isolated POU domain can serve to activate transcription weakly in the absence of additional information (Gerster et al. 1990; Ingraham et al. 1990; Müller-Immerglück et al. 1990). On the basis of these data, both the POU $\mathrm{S}_{\mathrm{S}}$ and the POU $\mathrm{HD}_{\mathrm{H}}$ together appear to permit specific DNA-dependent and DNA-independent protein-protein interactions that may be functionally crucial in both binding and trans-activation. Moreover, it appears that both regions modify the specificity and the affinity of these proteins for their cognate recognition elements.

\section{Activation and regulation of POU-domain genes}

Activation of POU-domain proteins is linked to actions of morphogens and classic signal transduction pathways. 
On the basis of precedents in Drosophila for other classes of developmental regulators (Akam et al. 1987; Scott et al. 1989), the molecular mechanisms of activation and maturation of POU-domain proteins are likely to involve the actions of numerous other classes of transcriptional regulators. Oct-3/4, expressed early in development and in embryonic stem cells, is markedly inhibited by retinoic acid, which induces phenotypic alteration along several pathways (Jones-Villeneuve et al. 1983; Strickland and Mahdavi 1988). These events can also be mimicked by introduction of the c-jun gene (deGroot et al. 1990). The finding that Oct-3/4 and Tst$1 /$ SCIP/Oct- 6 are strongly and negatively regulated by retinoic acid provides a correlation between expression of these POU-domain proteins and early developmental commitment events (Schöler et al. 1989; Okamoto et al. 1990; Suzuki et al. 1990).

The cloning of the pit-1 gene has permitted an initial assessment of the regulatory mechanisms responsible for its initial activation and regulation (Chen et al. 1990; McCormick et al. 1990). Two Pit-1 binding and regulatory elements were identified in the pit-1 gene, flanking the cap site. The $5^{\prime}$ sequence was a positive regulatory element, conferring Pit-1-dependent gene expression, while the $3^{\prime}$ element was an inhibitory element, attenuating expression by 10 -fold (Chen et al. 1990). These data are consistent with an autoregulatory loop that seems to function in maintaining pit-1 gene expression, effecting, in a sense, a memory of cell commitment. The very low levels of pit-1 transcript and protein in the $d w$ genetic dwarfs are consistent with the model that pit-1 transcriptional autoregulation exerts an important function in maintenance of pit-1 gene expression ( $\mathrm{Li}$ et al. 1990). Functional elements in the pit-1 promoter that bind CREB (Chen et al. 1990; McCormick et al. 1990), could serve developmental regulatory functions. In this regard, it is intriguing that the Tst-1/SCIP/Oct-6 gene is transiently expressed during a phase of rapid cell division preceding the myelinating phases of Schwann cell differentiation stimulated by cAMP (Monuki et al. 1990).

\section{Conclusions}

The large family of POU-domain proteins appears to exert critical functions as developmental trans-activators of genes that define specific cell phenotypes and in the proliferation of these cell types within an organ. Unexpectedly, the majority of known mammalian POU-domain genes are expressed in distinct spatial and temporal patterns in the forebrain, an area that does not express classic homeo domain genes. POU-domain proteins may exert functions in development of neurons in this recently evolved portion of the central nervous system by mechanisms comparable to those exerted by Unc- 86 and Pit-1 in sensory neuron and anterior pituitary cell development, respectively.

The unique DNA-binding properties of the POU domain, and the additional protein-protein interactions permitted by both the $\mathrm{POU}_{\mathrm{S}}$ and $\mathrm{POU}_{\mathrm{HD}}$ sequences, may provide additional, critical advantages to forebrain devel- opment via both homodimeric and heterodimeric protein-protein interactions that could refine both the specificity and regulatory consequences of members of this class of transcription factor. The heterogeneous binding sites for POU-domain factors do not appear to be palindromic and are likely to exhibit differential functional responses to post-translationally modified POU-domain proteins, potentially permitting even more complex combinatorial patterns of positive and negative gene regulation. It now becomes of significant interest to elucidate potential POU-domain-protein interactions, to identify the physiological target genes, and to elucidate the precise roles of the large family of POU-domain proteins in development of specific organs, particularly the central nervous system.

\section{Acknowledgments}

The discussions, suggestions, and aid of Drs. Holly Ingraham, Jeffrey Voss, Xi He, E. Bryan Crenshaw III, Maurice Treacy, Ruoping Chen, Sen Li, Renée Gerrero, Eric Turner, Chijen Lin, and the assistance of Susan Inglis in preparing this manuscript are gratefully acknowledged. Experiments alluded to from this laboratory were performed under grant support from the $\mathrm{Na}$ tional Institutes of Health and the American Cancer Society. M.G.R. is an Investigator with the Howard Hughes Medical Institute.

\section{References}

Akam, M. 1987. The molecular basis for metameric patterns in the Drosophila embryo. Development 101: 1-22.

Anderson, K.A. 1987. Dorsal-ventral embryonic pattern genes of Drosophila. Trends Genet. 3: 91-97.

Bodner, M., J.-L. Castrillo, L.E. Theill, T. Deerinck, M. Ellisman, and M. Karin. 1988. The pituitary-specific transcription factor GHF-1 is a homeobox-containing protein. Cell 50: $267-275$.

Burglin, T., M. Finney, A. Coulson, and G. Ruvkun. 1989. Caenorhabditis elegans has scores of homeobox-containing genes. Nature 341: 239-243.

Castrillo, J.L., M. Bodner, and M. Karin. 1987. Purification of growth hormone-specific transcription factor GHF-1 containing homeobox. Science 243: 814-817.

Chalfie, M. and M. An. 1989. Genetic control of differentiation of the Caenorhabditis elegans touch receptor neurons. Science 243: 1027-1033.

Chalfie, M., H.R. Horvitz, and J.E. Sulston. 1981. Mutations that lead to reiterations in the cell lineages of $C$. elegans. Cell 24: 59-69.

Chen, R., H.A. Ingraham, M.N. Treacy, V.R. Albert, L. Wilson, and M.G. Rosenfeld. 1990. Autoregulation of Pit-1 gene expression is mediated by two cis-active promoter elements. Nature 346: 583-586.

Clerc, R.G., L.M. Corcoran, J.H. LeBowitz, D. Baltimore, and P.A. Sharp. 1988. The B-cell-specific Oct-2 protein contains POU box- and homeo-box-type domains. Genes \& Dev. 2: $1570-1581$.

Crenshaw III, E.B., K. Kalla, D.M. Simmons, L.W. Swanson, and M.G. Rosenfeld. 1989. Cell-specific expression of the prolactin gene in transgenic mice is controlled by synergistic interactions between promoter and enhancer elements. Genes \& Dev. 3: 959-972. 
deGroot, R.P., F.A. Kruyt, P.T vanderSaag, and W. Kruiger. 1990. Ectopic expression of c-jun leads to differentiation of P19 embryonic carcinoma cells. EMBO J. 9: 1831-1837.

Dollé, P., J.-L. Castrillo, L.E. Theill, T. Deerinck, M. Ellisman, and M. Karin. 1990. Expression of GHF-1 protein in mouse pituitaries correlates both temporally and spatially with the onset of growth hormone gene activity. Cell 60: 809-820.

Dreyfus, M., N. Doyen, and F. Rougeon. 1987. The conserved decanucleotide from the immunoglobulin heavy chain promoter induces a very high transcriptional activity in B-cells when introduced into an heterologous promoter. $E M B O F$. 6: $1685-1690$.

Eicher, E.M. and W.G. Beamer. 1980. New mouse $d w$ allele: Genetic location and effects on lifespan and growth hormone levels. J. Hered. 71: 187-190.

Elsholtz, H.P., V.R. Albert, M.N. Treacy, and M.G. Rosenfeld. 1990. A two-base change in a POU factor-binding site switches pituitary-specific to lymphoid-specific gene expression. Genes \& Dev. 4: 43-51.

Finney, M., G. Ruvkun, and H.R. Horvitz. 1988. The C. elegans cell lineage and differentiation gene unc- 86 encodes a protein containing a homeodomain and extended sequence similarity to mammalian transcription factors. Cell 55: 757769.

Finney, M. and G. Ruvkin. 1990. The unc-86 gene product couples cell lineage and cell identity in C. elegans. Cell 63: 895-905.

Fox, S.R., M.T.C. Jong, J. Casanova, S.F. Ye, F. Stanley, and H.H. Samuels. 1990. The homeodomain protein, Pit-1/Chf-1, is capable of binding to and activating cell-specific elements of both the growth hormone and prolactin gene promoters. Mol. Endocrinol. 4: 1069-1080.

Gehring, W.J. 1987. Homeoboxes in the study of development. Science 236: 1245-1252.

Gerster, T. and R.G. Roeder. 1988. A herpes virus transactivating protein interacts with transcription factor OTF-1 and other cellular proteins. Proc. Natl. Acad. Sci. 85: 6347-6351.

Gerster, T., C.G. Balmacedo, and R.G. Roeder. 1990. The cell type-specific octamer transcription factor OTF-2 has two domains required for the activation of transcription. EMBO $\mathrm{F}$. 9: 1635-1643.

Glass, C.K., S.M. Lipkin, O.V. Devary, and M.G. Rosenfeld. 1989. Positive and negative regulation of gene transcription by a retinoic acid-thyroid hormone receptor heterodimer. Cell 59: 697-708.

Hanes, S. and R. Brent. 1989. DNA specificity of the bicoid activator protein is determined by homeodomain recognition helix residue 9. Cell 57: 1275-1283.

Hatzopoulos, A.K., A.S. Stoykova, J.R. Erselius, M. Golding, T. Neuman, and P. Gruss. 1990. Structure and expression of the mouse Oct $2 a$ and Oct $2 b$, two differentially spliced products of the same gene. Development 109: 349-362.

He, X., M.N. Treacy, D.M. Simmons, H.A. Ingraham, L.W. Swanson, and M.G. Rosenfeld. 1989. Expression of a large family of POU-domain regulatory genes in mammalian brain development. Nature 340: 35-42.

He, X., R. Gerrero, D.M. Simmons, R.E. Park, C.R. Lin, L.W Swanson, and M.G. Rosenfeld. 1991. Tst-1, a member of the POU-domain gene family, binds the promoter of the gene encoding the cell surface adhesion molecule Po. Mol. Cell. Biol. 2: 1739-1744.

Herr, W., R.A. Sturm, R.G. Clerc, L.M. Corcoran, D. Baltimore, P.A. Sharp, H.A. Ingraham, M.G. Rosenfeld, M. Finney, G. Ruvkun, and H.R. Horvitz. 1988. The POU domain: A large conserved region in the mammalian pit-1, oct-1, oct-2, and Caenorhabiditis elegans unc-86 gene products. Genes \&
Dev. 2: 1513-1516.

Ingham, P.W. 1988. The molecular genetics of embryonic pattern formation in Drosophila. Nature 335: 25-34.

Ingraham, H.A., R. Chen, H.J. Mangalam, H.P. Elsholtz, S.E. Flynn, C.R. Lin, D.M. Simmons, L. Swanson, and M.G. Rosenfeld. 1988. A tissue-specific transcription factor containing a homeodomain specifies a pituitary phenotype. Cell 55: 519-529.

Ingraham, H.A., S.E. Flynn, J.W. Voss, V.R. Albert, M.S. Kapiloff, L. Wilson, and M.G. Rosenfeld. 1990. The POU-specific domain of Pit-1 is essential for sequence-specific, high affinity DNA binding and DNA-dependent Pit-1-Pit-1 interactions. Cell 61: 1021-1033.

Johnson, W.A., and J. Hirsch. 1990. Binding of a Drosophila POU-domain protein to a sequence element regulating gene expression in specific dopaminergic neurons. Nature 343: 467-470.

Jones-Villeneuve, E.M.V., M.A. Rudnicki, J.K. Harris, and M.W. McQuerney. 1983. Retinoic acid-induced neural differentiation of embryonal carcinoma cells. Mol. Cell. Biol. 3: 22712279.

Kissinger, C.R., B. Liu, E. Martin-Blanco, T.B. Kornberg, and C.O. Pabo. 1990. Crystal structure of an engrailed homeodomain-DNA complex at $2.8 \AA$ resolution: A framework for understanding homeodomain-DNA interactions. Cell 63: $579-590$.

Ko, H.-S., P. Fast, W. McBride, and L.M. Staudt. 1988. A human protein specific for the immunoglobulin octamer DNA motif contains a functional homeobox domain. Cell 55: 135144.

Kristie, T.M. and P.A. Sharp. 1990. Interactions of the Oct-1 POU subdomains with specific DNA sequences and with the HSV $\alpha$-transactivator protein. Genes \& Dev. 4: 23832396.

Kristie, T.M., J.H. LeBowitz, and P.A. Sharp. 1989. The octamer binding proteins form multiprotein DNA complexes with the HSV $\alpha$ TIF regulatory protein. EMBO J. 8: 4229-4238.

LeBowitz, J.H., R.G. Clerc, M. Brenowitz, and P. Sharp. 1989. The Oct-2 protein binds cooperatively to adjacent octamer sites. Genes \& Dev. 3: 1625-1638.

Li, S., E.B. Crenshaw, E.J. Rawson, D.M. Simmons, L.W. Swanson, and M.G. Rosenfeld. 1990. Dwarf locus mutants lacking three pituitary cell types result from mutations in the POUdomain gene Pit-1. Nature 347: 528-533.

Lira, S.A., E.B. Crenshaw III, C.K. Glass, L.W. Swanson, and M.G. Rosenfeld. 1988. Identification of rat growth hormone genomic sequences targeting pituitary expression in transgenic mice. Proc. Natl. Acad. Sci. 85: 4755-4759.

Mangalam, H.J., V.R. Albert, H.A. Ingraham, M. Kapiloff, L. Wilson, C. Nelson, H. Elsholtz, and M.G. Rosenfeld. 1989. A pituitary POU domain protein, Pit-1, activates both growth hormone and prolactin promoters transcriptionally. Genes \& Dev. 3: 946-958.

McCormick, A., H. Brady, L.E. Theill, and M. Karin. 1990. Regulation of the pituitary-specific homeobox gene GHF-1 by cell autonomous and environmental cues. Nature 345: 829832.

McKnight, J.L.C., T.M. Kristie, and B. Roizman. 1987. Binding of the virion protein mediating $\alpha$ gene induction in herpes simplex virus 1-infected cells to its cis site requires cellular proteins. Proc. Natl. Acad. Sci. 84: 7061-7065.

Monuki, E.S., R. Kuhn, G. Weinmaster, B. Trapp, and G. Lemke. 1990. Expression and activity of the POU transcription factor SCIP. Science 249: 1300-1303.

Müller, M., S. Ruppert, W. Schaffner, and P. Matthias. 1988. A cloned octamer transcription factor stimulates transcription 
from lymphoid-specific promoters in non-B cells. Nature 336: 544-551.

Müller-Immerglück, M.M., W. Schaffner, and P. Matthias. 1990. Transcription factor Oct-2A contains functionally redundant activating domains and works selectively from a promoter but not from a remote enhancer position in non-lymphoid (HeLa) cells. EMBO I. 9: 1625-1634.

Murré, C., P.S. McCaw, and D. Baltimore. 1989a. A new DNA binding and dimerization motif in immunoglobulin enhancer binding, daughterless, MyoD, and myc proteins. Cell 56: $777-783$.

Murré, C., P.S. McCaw, H. Vaessin, M. Caudy, L.Y. Jan, Y.N. Jan, C.V. Cabrera, J.N. Buskin, S.D. Hauschka, A.B. Lassar, H. Weintraub, and D. Baltimore. 1989b. Interactions between heterologous helix-loop-helix proteins generate complexes that bind specifically to a common DNA sequence. Cell 58: 537-544.

Nelson, C., V.R. Albert, H.P. Elsholtz, L.E.-W. Lu, and M.G. Rosenfeld. 1988. Activation of cell-specific expression of rat growth hormone and prolactin genes by a common transcription factor. Science 239: 1400-1405.

Nüsslein-Volhard, C. and E. Wieschaus. 1980. Mutations affecting segment number and polarity in Drosophila. Nature 287: 795-801.

O'Hare, P. and C.R. Goding. 1988. Herpes simplex virus regulatory elements and the immunoglobulin octamer domain bind a common factor and are both targets for virion transactivation. Cell 52: 435-445.

Okamoto, K., H. Okazawa, A. Okuda, M. Sakai, M. Muramatsu, and H. Hamada. 1990. A novel octamer transcription factor is differentially expressed in mouse embryonic cells. Cell 60: $461-472$.

Olson, E.N. 1990. MyoD family: A paradigm for development? Genes \& Dev. 4: 1454-1461.

Otting, G., Y.Q. Qian, M. Müller, M. Affolter, W. Gehring, and L. Wüthrich. 1988. Secondary structure determination for the Antennapedia homeodomain by nuclear magnetic resonance and evidence for a helix-turn-helix motif. EMBO $\%$. 7: 4305-4309.

Otting, G., Y.-Q., Qian, M. Billeter, M. Müller, M. Affolter, W. Gehring, K. Wüthrich. 1990. Protein-DNA contacts in the structure of a homeodimer-DNA complex determined by nuclear magnetic resonance spectroscopy in solution. $E M B O$ J. 9: 3085-3092.

Poellinger, L. and R.G. Roeder. 1989. Octamer transcription factors 1 and 2 each bind to two different functional elements in the immunoglobulin heavy-chain promoter. Mol. Cell. Biol. 9: $747-756$.

Poellinger, L., B.K. Yoza, and R.G. Roeder. 1989. Functional cooperativity between protein molecules bound at two distinct sequence elements of the immunoglobulin heavychain promoter. Nature 337: 573-576.

Preston, C.M., M.C. Frame, and M.E.M. Campbell. 1988. A complex formed between cell components and an HSV structural polypeptide binds to a viral immediate early gene regulatory DNA sequences. Cell 52: 425-434.

Rauscher, F.J., D.R. Cohen, T. Curran, T.J. Bos, P.R. Vogt, D. Bohmann, R. Tjian, and B.R. Franza. 1988. Fos-associated protein P39 is the product of the jun proto-oncogene. Science 240: 1010-1016.

Rosner, M.H., M.A. Vigano, K. Ozato, P.M. Timmons, F. Poirier, P.W.J. Rigby, and L.M. Staudt. 1990. A POU-domain transcription factor in early stem cells and germ cells of the mammalian embryo. Nature 345: 686-691.

Roux, M., A. Bartke, F. Dumont, and M.P. Dubois. 1982. Immunohistological study of the anterior pituitary gland-pars distalis and pars intermedia-in dwarf mice. Cell Tissue Res. 223: 415-420.

Ruvkun, G. and M. Finney. 1991. Regulation of transcription and cell identity by POU-domain proteins. Cell 64: 475-478.

Scheidereit, C., J.A. Cromlish, T. Gerster, K. Kawakami, C.-G. Balmaceda, R.A. Currie, and R.G. Roeder. 1988. A human lymphoid-specific transcription factor that activates immunoglobulin genes in a homeobox protein. Nature 336: 552557.

Schöler, H.R., A.K. Hatzopoulos, R. Balling, N. Suzuki, and P. Gruss. 1989. A family of octamer-specific proteins present during mouse embryogenesis: Evidence for germline-specific expression of an oct factor. EMBO I. 8: 2543-2550.

Schöler, H.R., S. Ruppert, R. Balling, N. Suzuki, K. Chowdhury, and P. Gruss. 1990a. New type of POU domain in germ linespecific protein Oct-4. Nature 344: 435-439.

Schöler, H.R., G.R. Dressler, R. Balling, H. Rohdewohld, and P. Gruss. 1990b. Oct-4: A germline-specific transcription factor mapping to the mouse t-complex. EMBO $/$. 9: 2185-2195.

Schreiber, E., P. Matthias, M.N. Müller, and W. Schaffner. 1988. Identification of a novel lymphoid specific octamer binding protein (OTF-2B) by proteolytic clipping bandshift assay (PCBA). EMBO I. 7: 4221-4229.

Scott, M.P., J.W. Tamkun, and G.W. Hartzell. 1989. The structure and function of the homeodomain. Biochim. Biophys. Acta. 989: 25-48.

Sharp, Z.D. and Z. Cao. 1990. Regulation of cell-type-specific transcription and differentiation of the pituitary. Bioessays 12: $80-85$.

Simmons, D.M., J.W. Voss, H.A. Ingraham, J.M. Holloway, R.S. Broide, M.G. Rosenfeld, and L.W. Swanson. 1990. Pituitary cell phenotypes involve cell-specific Pit-1 mRNA translation and synergistic interactions with other classes of transcription factors. Genes \& Dev. 4: 695-711.

Singh, H., R. Sen, D. Baltimore, and P. Sharp. 1986. A nuclear factor that binds to a conserved sequence motif in transcriptional control elements of immunoglobulin genes. Nature 319: 154-158.

Snell, G.D. 1929. Dwarf, a new Mendelian recessive character of the house mouse. Proc. Natl. Acad. Sci. 15: 733-734.

Stern, S.A., M. Tanaka, and W. Herr. 1989. The Oct-1 homeodomain direct formation of a multiprotein-DNA complex with the HSV transactivator VP16. Nature 341: 624.

Sternberg, P.W. and H.P. Horvitz. 1984. The genetic control of cell lineage during neomatode development. Annu. Rev. Genet. 18: 489-524.

Strickland, S, and V. Mahdavi. 1981. The induction of differentiation in teratocarcinoma stem cells by retinoic acid. Cell 15: 393-403.

Sturm, R.A. and W. Herr. 1988. The POU-domain is a bipartite DNA-binding structure. Nature 336: 601-604.

Sturm, R.A., G. Das, and W. Herr. 1988. The ubiquitous octamer-binding protein Oct-1 contains a POU domain with a homeo box subdomain. Genes \& Dev. 2: 1582-1599.

Suzuki, N., H. Rohdewohld, T. Neuman, P. Gruss, and H.R. Schöler. 1990. Oct-6: A POU domain transcription factor expressed in embryonal and stem cells and in the developing brain. EMBO I. 9: 3723-3732.

Tanaka, M. and W. Herr. 1990. Differential transcriptional activation by Oct-1 and Oct-2: Interdependent activation domains induce Oct-2 phosphorylation. Cell 60: 375-386.

Tanaka, M., U. Grossniklaus, W. Herr, N. Hernandez. 1988. Activation of the U2 snRNA promoter by the octamer motif defines a new class of RNA polymerase II enhancer elements. Genes \& Dev. 2: 1764-1778.

Theill, L.E., J.W. Castrillo, D. Wu, and M. Karin. 1989. Dissec- 
tion of functional domains of the pituitary-specific transcription factor GHF-1. Nature 342: 945-948.

Treacy, M.N., X. He, and M.G. Rosenfeld. 1991. I-POU: A novel POU-domain protein inhibiting neuron-specific gene activation via heterodimer formation. Nature (in press).

Treisman, J., P. Gonczy, M. Vishishtha, E. Harris, and C. Desplan. 1989. A single amino acid can determine the DNA binding specificity of homeodomain proteins. Cell 59: 553562.

Verrijzer, C.P., A.J. Kal, and P.C. van der Vliet. 1990a. The DNA binding domain (POU domain) of transcription factor Oct-1 suffices for stimulation of DNA replication. EMBO $J$. 9: $1883-1888$.

1990b. The oct-1 homeo domain contacts only part of the octamer sequence and full oct-1 DNA-binding activity requires the POU-specific domain. Genes \& Dev. 4: 19641974.

Voss, J.W., L. Wilson, and M.G. Rosenfeld. 1991. POU-domain proteins Pit-1 and Oct-1 interact to form a heteromeric complex and can cooperate to induce regulation of the protein promoter. Genes \& Dev. (in press).

Wilson, D.B. and D.P. Wyatt. 1986. Ultrastructural immunocytochemistry of somatotrophs and mammotrophs in embryos of the dwarf mutant mouse. Anat. Rec. 215: 282-287.

Wirth, T., L. Staudt, and D. Baltimore. 1987. An octamer oligonucleotide upstream of a TATA motif is sufficient for lymphoid-specific promoter activity. Nature 329: 174-178. 


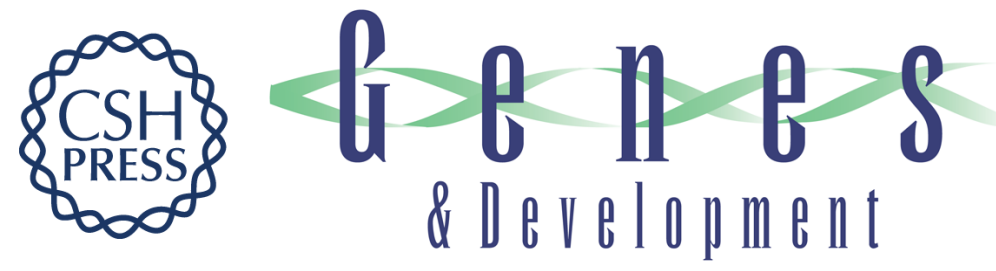

\section{POU-domain transcription factors: pou-er-ful developmental regulators.}

M G Rosenfeld

Genes Dev. 1991, 5:

Access the most recent version at doi:10.1101/gad.5.6.897

References This article cites 85 articles, 25 of which can be accessed free at:

http://genesdev.cshlp.org/content/5/6/897.full.html\#ref-list-1

License

Email Alerting

Service

Receive free email alerts when new articles cite this article - sign up in the box at the top right corner of the article or click here.

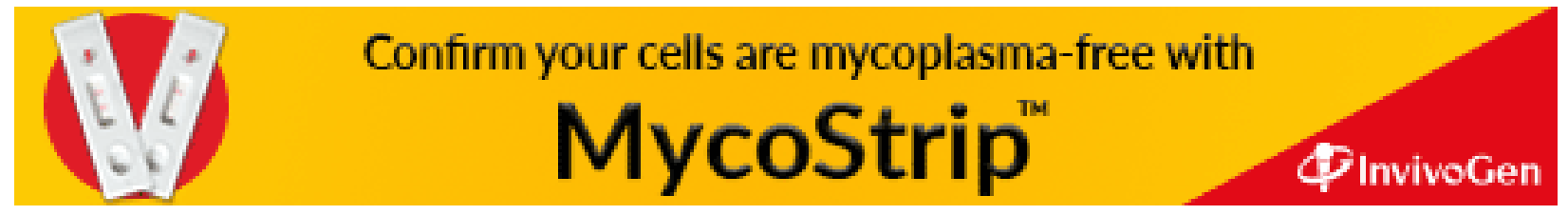

